\title{
What Counts as Prostitution?
}

\author{
STUART P. GREEN*
}

\section{Introduction}

What counts, or should count, as prostitution? In the criminal law today, prostitution is understood to involve the provision of sexual services in exchange for money or other benefits. But what exactly is a 'sexual service'? Is it prostitution to receive a fee in return for sexual conduct that does not involve penetration or other touching of the genitals (such as lap dancing)? Is it prostitution if there is no physical contact at all between the seller and another person (as when the buyer pays to watch the seller strip or masturbate), or if the only physical contact is between the seller and a third party (as when the buyer pays others to perform in a sex show or the filming of a pornographic movie)? And what exactly is the nature of the required 'exchange'? Is it prostitution if, in return for sex, a person gives money to his spouse or other steady sexual partner? Is it prostitution if sex is provided in return for money in the context of a 'therapeutic' relationship? Would it be prostitution if a person agreed to exchange sex in return for non-propertised benefits such as a job promotion or political favour? Would it be prostitution if a person accepted money as 'thanks' for having sex, or for her incidental 'expenses', rather than pursuant to a quid pro quo agreement?

Despite the enormous literature that exists on the law and morality of prostitution, there has been hardly any attention paid to basic definitional questions of this sort. Even

* Distinguished Professor of Law, Rutgers University; Leverhulme Visiting Professor of Law, London School of Economics (2016-17). Thanks to Andrew Ashworth, Sherry Colb, Jeremy Horder, Niki Lacey, Peter de Marneffe, and an anonymous reviewer for this journal for reading and commenting on an earlier draft. Thanks also to the attendees at a workshop at the Israel Institute for Advanced Studies, Hebrew University of Jerusalem, for their helpful questions and comments. This article is part of a larger, book-length project tentatively titled Criminalizing Sex: A Unified Theory.

This is an Open-access article distributed under the terms of the Creative Commons Attribution 3.0 Unported License (http://creativecommons.org/licenses/ by/3.0/, permitting all use, distribution, and reproduction in any medium, provided the original work is properly cited. 
otherwise philosophically sophisticated commentators seem content with a know-itwhen-they-see-it' approach. ${ }^{1}$ And the few courts that have considered one or another of these definitional questions have proceeded on an ad hoc basis, referring only to local law, and without any attempt at systematization. ${ }^{2}$

Deciding what should count as prostitution is not likely to be easy. The concept of prostitution is deeply embedded within complex cultural, moral, and legal constructs, all highly contested. Indeed, there is probably no type of sexual offence the moral and legal status of which has generated broader disagreement among scholars and legislatures alike. There is controversy even about the term 'prostitution' itself. ${ }^{3}$

Notwithstanding such obstacles, I believe that the definitional project is one worth pursuing. The key is to recognize that how we choose to define prostitution will inevitably depend on why we believe one or more aspects of prostitution are wrong or harmful, or should be criminalized or otherwise deterred, in the first place. These judgements, in turn, will often depend on an assessment of the contested empirical evidence on which they rest.

The analysis that follows consists of four basic steps: I begin with some initial thoughts on what 'prostitution' means in ordinary language and culture. Second (and this is really the heart of the paper), I consider how the 'what counts as prostitution' question has arisen in a variety of real-world contexts, paying particular attention to two sub-issues: what counts as 'sexual activity', and what counts as an 'exchange for property'. Third, I briefly describe (without adjudicating among) five leading rationales that have been offered to explain why prostitution is wrong or should be deterred or discouraged. I seek to show how our answer to these normative questions will ultimately determine our answer to the definitional one. Finally, I offer some preliminary thoughts on how analogous questions about what should count as sexual conduct arise in the context of consensual offences such as adultery and incest, and non-consensual offences such as sexual assault.

\section{2. 'Prostitution' in Ordinary Language}

Before we consider what 'prostitution' means in law, it will be useful to consider what it means in ordinary language. In current usage, 'prostitution' is understood to refer to the

1 See, e.g., Ericsson, Charges Against Prostitution: An Attempt at a Philosophical Argument, 90 Ethics (1980), p. 335, at 348 ('In this essay, I have deliberately desisted from trying to define "prostitution". I have simply relied upon the fact that we seem to know pretty well what we mean by this term.').

2 Several of these cases are briefly considered in an annually revised student survey published by Georgetown Law School. See Prostitution and Sex Work, 16 Georgetown J. of Gender and the Law, eds. Augustson and George (2015), p. 229, at 233-236.

3 See text accompanying note 7 below. 
practice of providing sexual services for payment; and 'prostitute' refers to the person who offers or agrees to sell such services. ${ }^{4}$ At its heart, then, prostitution seems to involve a commercial transaction.

Historically, however, the term 'prostitute' was often used to refer not only to those who offered sex for money, but also to those (especially women) who offered sex on an 'indiscriminate' basis, whether or not they were being paid. ${ }^{5}$ And it is this sense of indiscriminate sex that also shades into a highly pejorative, largely metaphorical, and less gender-specific sense of the term-namely, that one who 'prostitutes' oneself is a 'sell out', putting her talents and energies to an unworthy or corrupt use for personal gain. ${ }^{6}$

In addition to people who 'prostitute themselves', we can also talk about people who 'are prostituted. This sense clearly includes sex workers who are coerced into selling sex by a sex trafficker or pimp. But it might also refer, again in a metaphorical sense, to persons who are coerced by others, say, to support a cause they find morally abhorrent. When $A$ 'is prostituted, the person who has done this to her bears the responsibility for whatever harms are done to $A$ or to third parties. By contrast, when $A$ 'prostitutes herself', she is ostensibly responsible for what harm she causes (whether to herself or others).

Many commentators have been concerned about the fact that the terms 'prostitution' and 'prostitute' not only describe, but also often denounce. 7 To call someone a 'prostitute' can be highly derogatory. Even as a purely descriptive term, 'prostitution' is problematic, since it seems to apply exclusively to the practice of selling sex. That is, we would not ordinarily say that a person who buys sex was a prostitute, or even that he was engaged in prostitution. From a criminal law perspective, prostitution is better understood as a transaction that involves both a seller and a buyer.

The most commonly offered alternatives to 'prostitute' and 'prostitution' are 'sex worker' and 'sex work' (or 'commercial sex', as the proposed Model Penal Code

4 'Prostitution,' in Oxford English Dictionary, http://www.oxforddictionaries.com/us/definition/ american_english/prostitution

5 The etymology here is suggestive. The term 'prostitution' is derived from the Latin prostituere, which means 'to expose publicly'. The notion of 'sex for hire' is therefore not inherent in the etymology, which rather suggests sex that is 'publicly' or perhaps 'indiscriminately' offered. Online Etymology Dictionary, http://www.etymonline.com/index.php?term=prostitute. The idea of prostitution involving indiscriminate sex persisted in U.S. law until fairly recently. For example, at the time the original Model Penal Code was promulgated, sixteen states defined prostitution to include non-commercial promiscuous sex. Model Penal Code $\$ 207.12$, Commentary at 175 , note 24 (Tent. Draft No. 9, 1959).

6 To prostitute oneself in this figurative sense need not even involve sex: for example, an artist can prostitute herself by making bad, but commercially-successful, art. Nor need the reward be financial: A politician can prostitute herself by compromising her principles for the purpose of winning an election or appointment to high office.

7 See, e.g., Law, Commercial Sex: Beyond Decriminalization, 73 Southern California L. Rev. (2000), p. 523 , at 525 . 
provision would have it). ${ }^{8}$ For purposes of the present project, however, the terms 'sex work' and 'sex worker' are both too narrow and too broad. They are too narrow because, like the term 'prostitution', they apply only to the supply, rather than the demand, side of the transaction. And they are too broad because they would seem to apply not only to prostitution in the traditional sense of the term, but also to more remote activities such as pimping and running a brothel, dancing in a strip club, acting in a pornographic movie, working for a telephone sex service, or advertising sexual services. To group all of them together would, if nothing else, pose a problem for the principle of fair labeling. ${ }^{9}$

Rather than refer to 'prostitution' or 'sex work', I think we would do better to talk about 'selling sex' and 'buying sex'. But even these terms do not offer a perfect solution, since they suffer from at least some of the same ambiguity as 'sex work' itself. As we shall see below, whether the people who work for, or patronise, a strip club or phone sex service can be said to be selling or buying sex ultimately depends on what we mean by 'sex' and what we mean by 'buying.

\section{Prostitution Defined in Law}

Having considered how 'prostitution' is used in ordinary language, we now turn to the main subject of the inquiry-namely, how it is defined in the law. As we shall see, the answer to this question has varied considerably from jurisdiction to jurisdiction.

At first glance, such variety is not surprising. There is probably no area of substantive criminal law that reflects more variation in how it is formulated. Looking at just the law of Western, industrialized nations, and only at statutes involving adults, we can identify at least the following five basic models:

(1) criminalise the buying and selling of sex, as well as related activities such as street walking, kerb crawling, pimping, and brothel-keeping (the policy in most U.S. jurisdictions);

(2) criminalise the buying of sex and other related activities by pimps and clients, including brothel-keeping, but don't criminalise the sale of sex or related activities by sellers (the policy in Sweden, Norway, Iceland, Finland, Northern Ireland, Canada, and, most recently, France);

Model Penal Code $\$$ 213.0(2) (September 15, 2015 draft).

See generally Ashworth, Principles of Criminal Law (Oxford University Press, 4th ed. 2003), pp. 89-90; Chalmers and Leverick, Fair Labelling in Criminal Law, 71 Modern L. Rev. (2008), p. 217, at 239; Green, Thirteen Ways to Steal a Bicycle: Theft Law in the Information Age (Harvard U. Press, 2012), pp. 52-54. 
(3) criminalise prostitution-related activities such as streetwalking, kerb crawling, pimping, and brothel-keeping, but don't criminalise the buying or selling of sex as such (the policy in England, Wales, and Scotland)

(4) criminalise pimping and brothel-keeping, but don't criminalise the purchase or sale of sex as such or other activities by sellers (the policy in Denmark and Israel); and

(5) don't criminalise any prostitution-related activities other than trafficking and forced prostitution, but license, impose age limitations and regulate matters of health and safety (the policy in Germany, the Netherlands, New Zealand, and Nevada). ${ }^{10}$

One might imagine that those jurisdictions that shared a particular approach to criminalisation would also share an approach to defining prostitution, and vice versa. But, as it turns out, that is not the case at all. In practice, there is little correlation between the manner in which prostitution is criminalised and how the act itself is defined.

So, how has the basic transaction that constitutes the offense of selling or buying sex been defined? We can begin by identifying three basic approaches the statutes have taken. One group of (mostly older) offense provisions makes it a crime simply to 'be a prostitute,' 'engage in an act of prostitution,' or (in Iceland ${ }^{11}$ ) 'pay for prostitution'-without any additional explanation of what it means to be such a person or engage in such an act. ${ }^{12}$ Defining the offense of prostitution in this way is both circular and vague. It gives potential offenders, law enforcement, and courts essentially no instruction about which acts are prohibited. Moreover, it is potentially both under- and overinclusive. It is underinclusive in the sense that it might be understood to exclude the buying of sex, as well as the selling of sexual acts other than intercourse. It is overinclusive in the sense that it could conceivably be understood to include prostitution in its non-commercial, merely 'promiscuous', sense. One would think that so vague and circular an offense definition would be ripe for constitutional challenge. But, in fact, vagueness and overbreadth challenges have been almost uniformly unsuccessful in this context. ${ }^{13}$

10 This summary is adapted from de Marneffe, Liberalism and Prostitution (Oxford U. Press 2010), pp. 28-31.

11 See Iceland Penal Code, Section 206 (2009) (making it a crime to 'pay . . . or promise ... to pay or render consideration of another type, for prostitution', without any additional explanation of what constitutes the act).

12 This is the approach used by statutes in Arizona, California, Maine, Michigan, Mississippi, and South Carolina. For a useful compendium of U.S. prostitution statutes, though with very little analysis, see generally Posner and Silbaugh, A Guide to America's Sex Laws (U. Chicago Press, 1996), pp. 155-187.

13 See Baldwin, Split at the Root: Prostitution and Feminist Discourses of Law Reform, 5 Yale J.L. \& Feminism (2002), p. 47, at $67 \&$ n.60 (citing representative cases). 
A more modern approach to defining prostitution is to specify what it is that must be bought or sold. In a majority of U.S. states, ${ }^{14}$ as well as in England and Wales, ${ }^{15}$ Norway, ${ }^{16}$ and Sweden, ${ }^{17}$ this is done by referring to the sale or purchase of 'sexual activity', 'sexual services', or 'sexual contact', sometimes with further specification of acts, but often without. A few other jurisdictions prohibit the sale or purchase of conduct that is 'lewd,' a notoriously vague term that in this context seems to mean something like 'tend[ing] to incite sensual desire or imagination. ${ }^{18}$ Defining prostitution as 'sexual' or 'lewd' conduct for hire may be a bit better than referring simply to 'being a prostitute,' but it hardly solves the problem of vagueness. By itself, the term gives us almost no direction on how to decide puzzling cases involving conduct such as oral sex, manual-genital stimulation, lap dancing, or stripping.

The final means of defining prostitution is to enumerate exactly which sexual acts for hire are prohibited. While this approach would seem to solve the problem of vagueness and overbreadth, it nevertheless raises questions of policy. Which acts should be included here? It is probably no surprise that every U.S. state that follows the enumeration approach includes on its list of prohibited acts that of 'sexual intercourse. ${ }^{19}$ But beyond that, it is striking how little consensus there is. Other specific acts that are listed in one or more, but by no means all, statutes include fellatio, cunnilingus, anal intercourse, manual genital touching, sadomasochistic abuse, and flagellation. ${ }^{20}$

\section{Defining 'Sexual Activity'}

Having surveyed the various ways in which prostitution is statutorily defined, we now consider several specific contexts in which questions have arisen, or could arise, about

14 See statutes in Alaska, Arkansas, Connecticut, Delaware, Florida, Hawaii, Iowa, Massachusetts, Missouri, Nevada, New Hampshire, New Jersey, New Mexico, New York, North Dakota, Ohio, Oregon, Pennsylvania, South Dakota, Tennessee, Texas. See also Model Penal Code $\$ 2017.12(1)$ (referring to 'sexual activity for hire'). The proposed Draft Model Penal Code Revision of September $15,2015, \$ 213.0(2)$ refers to 'any act of sexual penetration or sexual contact.'

15 English Sexual Offences Act 2003, Section 51(2) (requiring that offender offer or provide 'sexual services to another person in return for payment').

16 Norwegian General Civil Penal Code, Section 316 (making it a crime to engage in 'sexual activity or commit a sexual act with another person for payment').

17 Swedish Criminal Code (Brottsbalk), Section 6.11 (criminalising 'purchase of sexual services').

18 See, e.g., Michigan ex rel. Wayne County Prosecutor v. Dizzy Duck, 535 N.W.2d 178, 183 (Mich. 1995).

19 The Finnish Criminal Code, Chapter 20, Section 8, also makes it a crime to engage, with a victim of the sex trade, in 'sexual intercourse' (though the precision of this provision is somewhat undercut by the addition of the phrase 'or a comparable sexual act').

$20 \quad$ See generally statutes listed in Posner and Silbaugh 1996, pp. 155-197. 
what should count as 'sexual activity'. I group these into three categories: (a) cases involving non-penetrative sexual contact between the seller and buyer; (b) cases involving no physical contact at all between the seller and buyer or between the seller and any third party; and (c) cases involving physical contact, including penetration, between the seller and a third party, but no physical contact between the seller and buyer.

\section{(a) Cases Involving Non-Penetrative Sexual Contact between Buyer and Seller}

Should it be prostitution if A engages in, or agrees to engage in, commercial sexual activity with $\mathrm{B}$ that does not involve penetration (whether vaginal, oral, or anal)? For example, is it prostitution to engage in 'lap dancing', in which a nude or partially nude dancer has bodily contact with a seated patron in a manner that is meant to be sexually stimulating? Is it prostitution if $A$ offers to engage in non-penetrative acts of domination and submission? Is it prostitution if A offers B a 'happy ending' massage (involving manual contact with the genitals)?

Those courts that have considered issues of this sort have tended to analyze them, as no doubt they should, in terms of the language of applicable law. For example, in the Hawaii case of Keawe, the defendant agreed to perform a lap dance for money. In determining whether such conduct constituted prostitution, the Hawaiian Supreme Court looked to the language of the relevant statute, which defined (1) 'prostitution' as 'sexual conduct with another person for a fee'; (2) 'sexual conduct' as 'sexual penetration' or 'sexual contact'; and (3) 'sexual contact' as 'any touching ... of the sexual or other intimate parts of a person.21 ${ }^{3}$ On the basis of this language, the court, properly it seems, concluded that lap dancing was indeed prostitution..$^{22}$ The Pennsylvania case of Cohen, involving a 'happy ending' massage, was to the same effect. ${ }^{23}$ Similarly, in the English case of Tan, the defendant was convicted of living off the earnings of prostitutes where customers were subjected to humiliation, flagellation, bondage, and torture, sometimes accompanied by masturbation, in return for pay. ${ }^{24}$

Elsewhere, reliance on statutory language has been less straightforward. For example, in the New York case of Georgia, the defendant agreed to perform foot licking, spanking, domination, and submission in exchange for a fee. ${ }^{25}$ The state's statute required that the

\footnotetext{
$21 \quad$ Hawaii Rev. Stat. $\$ 712-1200$.

$22 \quad$ Hawaii v. Keawe, 108 P.3d 304 (Hawaii 2005).

23 Commonwealth v. Cohen, 538 A.2d 582 (Pa. Super. Ct. 1988) (interpreting Pennsylvania Cons. Stat. Ann. Title 18, $\$ 5902$, which makes it a crime to engage in 'sexual activity as a business').

$24 \quad$ R. v. Tan and Others [1983] Q.B. 1053.

25 People v. Georgia, 163 Misc.2d 634 (N.Y. Crim. Ct. 1994).
} 
offender engage in 'sexual conduct', but did not define the term any more specifically. ${ }^{26}$ With little explanation, the court held that engaging in sadomasochistic conduct for a fee did not constitute prostitution under the statute. In dismissing the charges, the court viewed it as critical that there was no physical contact between the parties involving a 'person's clothed or unclothed genitals, buttocks or a woman's breasts.'

Cases in which the buyer pays to have contact with the seller's breasts also raise issues. Consider, for example, the Minnesota case of Oanes. ${ }^{28}$ The relevant statute defined prostitution as 'engaging or offering or agreeing to engage for hire in sexual penetration or sexual contact,' and it defined 'sexual contact' as including ' $t]$ he intentional touching by an individual of a prostitute's intimate parts. ${ }^{29}$ (The circularity of requiring that the defendant touch the 'prostitute's' intimate parts need hardly be noted.) The question was whether a woman's breasts should be regarded as 'intimate parts' within the meaning of the statute, and the court held that they should. Its reasoning? The court said simply that, ' $\mathrm{i}$ ] $\mathrm{n}$ the United States, women normally cover their breasts when in public and take offense at a stranger's touch. ${ }^{30}$

\section{(b) Cases Involving no Physical Contact between Seller and Buyer or any Third Party}

There is also a range of cases in which the buyer pays the seller to engage in sexual conduct that involves no physical contact between the seller and anyone else, including the buyer. The most common context in which this occurs is where the buyer pays to watch the seller strip or engage in self-masturbation.

I am not aware of any court holding that such conduct constitutes prostitution. The Australian case of Begley, involving charges of prostitution brought against a stripper, is representative. In dismissing the charge, the court simply asserted, without any explanation, that 'there must be some contact between the person offering the use of the body and the person paying the fee. ${ }^{31}$

One case that arguably tests the limits of this 'some contact' rule is State v. Turnpaugh. A man (Turnpaugh) offered to pay to watch a woman (Ferguson) masturbate

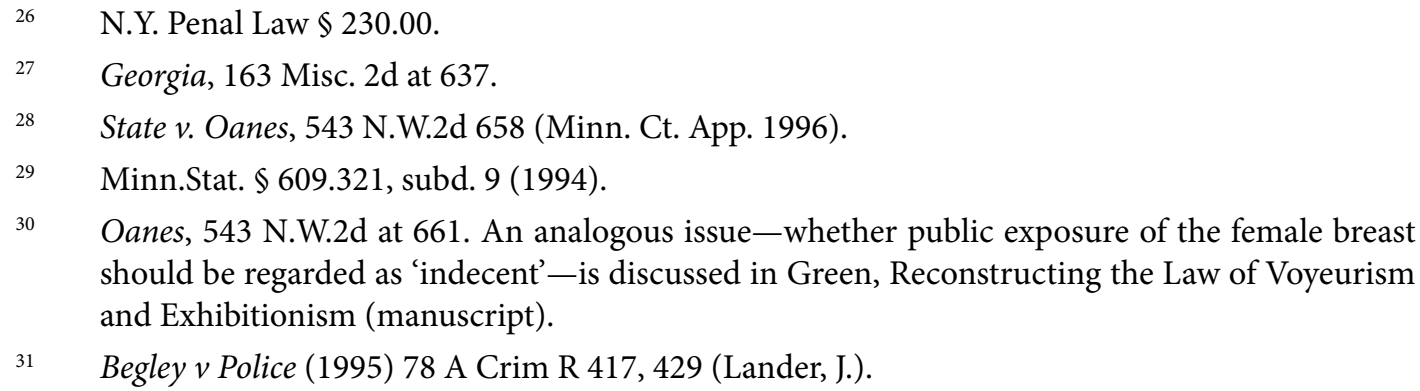


herself. ${ }^{32}$ The Wisconsin statute defined prostitution to include not just sexual intercourse and oral sex but also ' $[\mathrm{m}]$ asturbat[ing] a person or offer[ing] to masturbate a person or request[ing] to be masturbated by a person for anything of value. ${ }^{33}$ In the actual case, the person prosecuted was Turnpaugh (Ferguson, it turns out, was an undercover cop). Because none of these acts were be done to Turnpaugh, he escaped liability. But imagine that it was Ferguson who had been prosecuted instead. Since she did in fact offer to masturbate 'a person'-namely, herself-the statute arguably would have been satisfied, and she would have been liable. The Wisconsin statute thus presents a curious asymmetry which may or may not have been intended by the state legislature.

\section{(c) Cases involving physical contact between seller and a third party}

Perhaps the most puzzling cases concerning what should constitute 'sexual activity' for purposes of prostitution law are those in which the seller has sexual contact with someone other than the buyer. There are, essentially, two varieties here: cases in which the buyer pays for the seller to engage in sex with a third party for the third party's gratification (essentially, the buyer gives a gift to the third party); and those in which the buyer pays the seller to watch the seller engage in sex with a third party for the buyer's gratification.

The first type is illustrated by a rather salacious anecdote from a biography of the businessman Richard Branson, which reports that his first sexual experience was with a prostitute paid for by his father (apparently, a not uncommon practice among the English upper classes at the time). ${ }^{34}$ One can also imagine a case in which an employer or patron buys sexual services as a kind of gratuity for his employee or client, as the case may be. For example, in 2012, various gossip websites alleged that New Jersey Senator Bob Menendez, while on vacation in the Dominican Republic, received sexual services (from underage prostitutes, no less) paid for by a wealthy donor named Salomon Melgen. ${ }^{35}$

Is there an argument for exempting from liability the person who has the sex, or the person who pays the bill, in such cases? (To be clear, such cases would not qualify as 'pimping' in most jurisdictions, since the alleged buyer of sex-whether it was the

$32 \quad$ State v. Turnpaugh, 741 N.W.2d 488 (Wis. Ct. App. 2007).

33 Wis. Rev. Stat. $\$ 944.30(\mathrm{~d})$.

34 Moore, Review of Beyond the Mask by Tom Bower, in The Guardian (Feb. 12, 2014), http://www. theguardian.com/books/2014/feb/12/branson-behind-mask-tom-bower-review

35 Bob Menendez,Wikipedia, https://en.wikipedia.org/wiki/Bob_Menendez. Although the prostitution charges were never substantiated, Menendez was later indicted for accepting more than one million dollars in other gifts and campaign contributions from Melgen. 
elder Branson or Dr. Melgen-was not directly profiting from the agreement. ${ }^{36}$ ) A typical U.S. prostitution statute provides that it is a crime to 'engage in sexual conduct for a fee. ${ }^{\prime}{ }^{7 *}$ Would the statute be satisfied if $A$ had sex with $B$ when $B$ 's fee was paid for by a third party, $C$ ? There would be no problem in imposing liability on $B$, since she would have provided 'sex for a fee.' With respect to $A$ and $C$, however, the issue is more complicated. $A$ had sex, but arguably not 'for a fee'; and $C$ paid a fee, but did not have sex. So perhaps an argument could be made that such transactions would be exempt from prosecution..$^{38}$ The problem, of course, is that such a loophole would create an incentive for parties to engage in 'straw man' transactions. Presumably to avoid such confusion, a few modern statutes now address the issue explicitly. For example, under the Finnish statute, it is a crime to have sex with a victim of the sex trade even when 'remuneration [is] . . promised or given by a third person. ${ }^{39}$ Similarly, Swedish law says that a person is guilty of purchasing sexual services even when the 'payment was promised or given by another person' ${ }^{40}$

The second sort of case involving sex with a third party is even more puzzling. Consider Taylor v. Arizona. ${ }^{41}$ The defendants worked at a sex club where they were paid to have sex with each other while their customers sat on the other side of a glass pane and watched. In upholding the conviction, the court reasoned that while the statute did 'require a sexual contact between at least two people', it did not necessarily require contact 'between the prostitute and the customer.'42

Other jurisdictions have followed a different approach. The California case of Wooten v. Superior Court involved essentially the same facts as Taylor. ${ }^{43}$ This time, though, it was the managers of the club who were prosecuted for pimping and pandering, and the court held that no crime had been committed. Although the California statute did not specify

36 For example, under section 52 of the English Sexual Offences Act 2003, it is a crime for an offender to cause or incite another person to be a prostitute if he 'does so for or in the expectation of gain for himself or a third person' (typically by taking a cut of the prostitute's earnings). This is not the scenario I have in mind. In the scenario I have in mind, $A$ causes $B$ to give sexual services to $C$ without any expectation of monetary gain: $A$ is just giving a 'gift' to $C$.

37 E.g. Hawaii Rev. Stat. $\$ 712-1200$.

38 Alternatively, it might be possible to 'split' the actus reus between $A$ and $C$, and charge both under a theory of accomplice liability.

39 Finland Criminal Code, Chapter 20, Section 8.

$40 \quad$ Sweden Criminal Code, Ch. 6, § 11.

$41 \quad$ State v. Taylor, 167 Ariz. 429 (1990).

42 Id. at 430. The Arizona law defined 'prostitution' as 'engaging in or agreeing or offering to engage in sexual conduct with another person under a fee arrangement with that person or any other person'. Ariz. Rev. Stat. \$13-3211(5) (emphasis added). Wooten v. Superior Court, 113 Cal.Rptr.2d 195 (Cal. Ct. App. 2001). 
that there had to be physical contact between the sex seller and buyer, the court, relying on the principle of lenity, held that this was the better interpretation. ${ }^{44}$

The idea that prostitution must involve physical contact between a buyer and seller holds important implications for the multi-billion-dollar pornography industry. Much pornography depicts sexual acts involving two or more actors who are paid by a producer who is not himself engaged in such acts. The question thus arises whether the producer of such films could be prosecuted for prostitution or related charges.

In the leading case, People v. Freeman, the California Supreme Court said no. ${ }^{45}$ Freeman was a film producer who paid several actors to perform various sexual acts in front of a camera. He was prosecuted for 'pandering', which under the California Criminal Code consists of 'procur[ing] another person for the purpose of prostitution. ${ }^{36}$ In overturning his conviction, the court relied on three basic arguments: First, it said, there was 'no evidence that defendant paid the acting fees for the purpose of sexual arousal or gratification, his own or the actors. ${ }^{37}$ Second, it claimed, "[f] or a "lewd" or "dissolute" act to constitute "prostitution", the genitals, buttocks, or female breast, of either the prostitute or the customer must come in contact with some part of the body of the other', and that did not happen here. ${ }^{48}$ Finally, the court said, even if the defendant's conduct did fall within the literal definition of prostitution, 'the application of the pandering statute to the hiring of actors to perform in the production of a nonobscene motion picture would impinge unconstitutionally upon First Amendment values. ${ }^{39}$

All three statements are problematic: With respect to the first, it does not require much imagination to realise that, even if Freeman was not sexually aroused or gratified by the actors' conduct, the actors themselves probably were. The second statement suggests that liability for prostitution could be avoided whenever the prostitute's fee was paid for by a third party who was not himself engaged in sex, the very same loophole presented by cases like those involving Branson's father and Menendez's patron. Finally, as to the free speech argument, it is odd to think that an otherwise illegal act should become lawful simply because it was performed in front of a camera. Could one avoid liability for

$44 \quad$ Cal. Penal Code $\$ 647$ defined 'prostitution' to include 'any lewd act between persons for money or other consideration'.

$45 \quad$ People v. Freeman, 758 P.2d 1128 (Cal. 1988).

$46 \quad$ Cal. Penal Code $\$ 266$ i.

47 Freeman, 758 P.2d at 1130.

$48 \quad$ Id. at 1131.

49 Id. For a similar result, see State v. Washington-Davis, 867 N.W.2d 222 (Minn. Ct. App. 2015). The only case I am aware of that reaches a contrary decision is People v. Kovner, 409 N.Y.S.2d 349 (N.Y. Sup. Ct., 1978). 
prostitution by filming oneself having sex for money? And why would the same reasoning not apply to a murder or rape that was captured on film? ${ }^{50}$

\section{Exchange for Value}

In the paradigmatic case of prostitution, the seller of sex offers her services to essentially anyone who can pay her fee, in cash. In this section, we consider a variety of cases that do not fit this paradigm. We begin by examining (a) the quid pro quo nature of 'exchange.' We then turn to cases in which sex is exchanged for: (b) something other than money, such as economically valuable goods or services; (c) non-propertised things of value, such as a promotion at work; (d) money or other property within the context of a monogamous or relatively exclusive relationship; and (e) money or other property within the context of a 'therapeutic' relationship.

\section{(a) Quid Pro Quo Requirement}

One of the most basic requirements that defines the offense of prostitution is that sex be exchanged for money or other property. In practice, this means that receiving or giving something of value merely as 'thanks' for, or incident to, a sexual act, would not constitute prostitution. Rather, the transaction of sex for money must constitute a quid pro quo. As such, prostitution is analogous to bribery, which requires that something of value be given 'in exchange for' an official act. ${ }^{51}$

A good illustration of what this quid pro quo requirement means in practice can be seen in the the Hawaii case of Xiao. ${ }^{52}$ The defendant, Xiao, met Wagner, an undercover cop, at a nightclub in Honolulu. Wagner bought her several drinks, after which she slow danced' with him (i.e., rubbed her body against his body and groin area). Prosecuted for

50 For further commentary, pro and con, on treating pornography as prostitution, see Colb, The Legal Line between Porn and Prostitution, CNN.Com (Aug. 12, 20015), http://edition.cnn. com/2005/LAW/08/12/colb.pornography/; Kaye, Why Pornography is Not Prostitution: Folk Theories of Sexuality in the Law of Vice, 60 St. Louis U. L.J. 243 (2016); Waltman, The Ideological Obstacle: Charging Pornographers for Sexual Exploitation (2012), Midwest Political Science Association Conference, Chicago IL, April 11-15, 2012. Available at SSRN: http://ssrn.com/ abstract $=2050290$

51 See 18 U.S.C. C. $\$ 201($ b). Giving or receiving something of value as 'thanks' for an official act constitutes the lesser offense of giving or receiving a gratuity, see 18 U.S.C. $\$ 201$ (c), but there is no analogous offence in the context of prostitution. For discussion of the quid pro quo requirement in bribery, see Green, What's Wrong with Bribery, in Duff and Green, Defining Crimes: Essays on the Criminal Law's Special Part (Oxford U. Press, 2005), at pp. 143, 148-151.

$52 \quad$ State v. Jing Hua Xiao, 231 P.3d 968 (Hawaii 2010). 
selling sex, Xiao argued that there was no evidence that the drinks constituted a 'fee' and that any any sexual conduct that occurred between her and Wagner was 'merely gratuitous'. Perhaps surprisingly, given that the drinks cost forty dollars each, the Hawaii Supreme Court agreed with Xiao's contention. Even though there was nothing, in principle, to prevent the purchase of a drink from constituting the payment of a 'fee', the court said, the prosecution had failed to present sufficient evidence that Xiao had agreed to provide sex in return for the drinks.

\section{(b) Cases in which Sex is Exchanged for Economic Goods other than Money}

While all prostitution statutes require that sex be exchanged for something of value, they vary considerably in precisely how the thing of value is defined. Among U.S. statutes, prostitution is defined as sex 'for hire, ${ }^{53}$ for a 'fee,, ${ }^{54}$ 'as a business, ${ }^{55}$ that is 'purchased, ${ }^{56}$ or that is exchanged for 'money, ${ }^{57}$ 'money or its equivalent,, ${ }^{5 *}$ 'money or other property,' 'money, property, or services, ${ }^{60}$ or 'anything of value. ${ }^{61}$ Meanwhile, Icelandic law makes it a crime to pay or render 'consideration' in return for sex, ${ }^{62}$ while English and Norwegian law speak in terms of making or promising 'payment.'.63

Where the exchange is defined in broad terms, prostitution will be found to have been committed even in cases that do not reflect the traditional sex-for-cash paradigm. For example, under Indiana law, 'prostitution' is defined as 'sexual intercourse or deviate sexual conduct in return for money or other property', and 'property' is defined to include 'real property, personal property, money, labor, and services. ${ }^{64}$ With such a broad definition, it is no surprise that in the case of Edwards, the defendant was held liable for agreeing to provide sexual services in return for a 'ride across town' in her prospective customer's car. ${ }^{65}$ Similarly, under English law, which defines the term 'payment' to include 'any

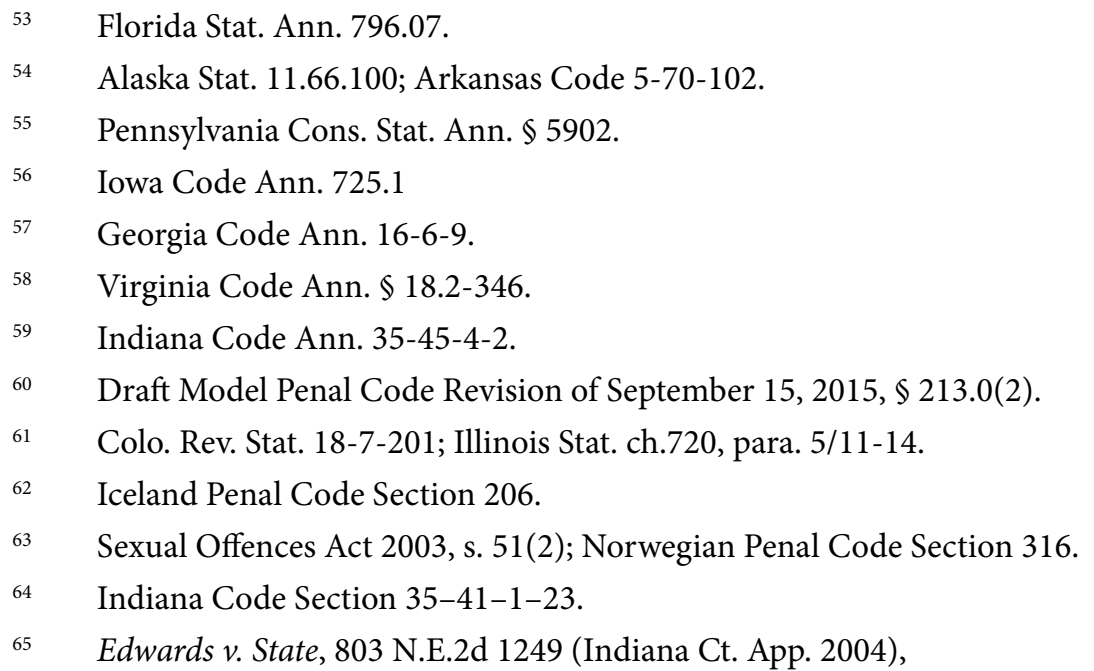


financial advantage, including the discharge of an obligation to pay, ${ }^{66}$ one would expect a court to find prostitution in a case in which a 'single mother ... [has] sex with her landlord in place of rent. ${ }^{3}$

By contrast, where the statutory language is narrow, a different result is to be expected. For example, in the Illinois case of Johnson, the defendant contended that the prostitution statute was unconstitutionally vague because it would 'make a "prostitute" of a woman who offers, performs or agrees to perform sexual acts in overt or tacit exchange for an expensive dinner or a concert, an exchange the defendant contends is part of an unwritten social code. ${ }^{68}$ In rejecting this vagueness argument, the court stated that the 'committee which drafted the statute specifically limited its language to apply only to sex acts performed for "money," instead of for "any valuable consideration." Thus, 'an offer or agreement to receive money, rather than, for example, a fur coat or a night at the opera ... is essential to a prostitution conviction'. To construe the statute otherwise, the court said, would have the untoward effect of interfering with what it called 'ordinary social situations', and 'discourag[ing] exchanges of sexual acts as a part of social companionship or for gifts of material goods ${ }^{\prime 69}$ Presumably, this strict sex-for-cash approach would also have the even more perverse effect of excluding a wide range of transactions in which sex is exchanged for drugs, cases that pose some of the most serious public health risks associated with commercialised sex. ${ }^{70}$

\section{(c) Sex in Return for Non-Propertised Goods}

All of the cases we have considered so far have involved the exchange of sex for property of some sort-whether money, services, or goods. We now turn to cases involving the exchange of sex for things not easily propertised, such as political favours or job promotions. While there is essentially no case law directly considering whether conduct of this sort should count as prostitution, the question is nevertheless worth posing.

66 Sexual Offences Act 2003, s. 51(2).

67 See Miller, Sugar Dating: A New Take on an Old Issue, 20 Buffalo J. Gender, Law \& Social Policy (2010), pp. 33, 40.

68 People v. Johnson, 376 N.E.2d 381, 385 (Ill. Ct. Ap. 1978) (interpreting Ill.Rev.Stat.1965, chap. 38, sec. 11-15).

69 Id. (citations omitted). The Illinois statute was subsequently broadened to refer to sex exchanged for 'anything of value'.

70 See Miller, Prostitution, in The Oxford Handbook of Crime and Public Policy, ed. Tonry (Oxford U. Press, 2011), pp. 547-577. 
Consider, for a start, the facts of Tunnel, a case from the U.S. Fifth Circuit. ${ }^{71}$ Tunnel owned the Pines Motel in Kilgore, Texas, which he effectively ran as a brothel. Russell was the local justice of the peace. Tunnel offered Russell sexual services in return for Russell's 'looking the other way' while criminal acts were being performed 'on his watch'. In the actual case, Tunnel was convicted of offering Russell a bribe. In rejecting Tunnel's argument that bribery under Texas law required 'pecuniary gain,' the court said it was sufficient that Russell had received the 'benefit' of sexual favours. ${ }^{72}$

Now imagine that, rather than being prosecuted for receiving or giving a bribe, Russell or Tunnel were prosecuted for prostitution. Although there do not appear to be any such cases on the books, it is worth asking whether sex given in exchange for a non-propertised 'benefit' of this sort should fall within the realm of prostitution law. In terms of most of the rationales for criminalising prostitution that we'll discuss belowprotecting religious values, preventing commodification of sex and the objectification of women, protecting the health of sex workers and the public, and preventing violence against and exploitation of women-it is hard to see why the result should be any different from a conventional case involving sex for money.

\section{(d) Exchanges Involving Sex with Spouses and Other 'Exclusive'Sexual Partners}

In the Tunnel case, Russell was just one of many 'customers' receiving sex from the women who worked at the Pines Motel. Would it have made any difference if the relationship between the 'buyer' and 'seller' had been more exclusive? In this section, we consider cases in which sex is exchanged for money or other property within spousal relationships, between so-called 'sugar daddies' and 'sugar babies', and in so-called 'office romances'.

Let us look first at spouses. As Martha Nussbaum and others have recognised, marriage and sex have always had an economic element:

$[\mathrm{M}]$ ost cultures contain a continuum of relations between women and men (or between same-sex pairs) that have a commercial aspect-ranging from the admitted case of prostitution to cases of marriage for money, going on an expensive date where it is evident that sexual favors are expected at the other end, and so forth. In most cultures, marriage itself has a prominent commercial aspect: the prominence of dowry murder in contemporary Indian culture, for example, testifies to the degree to which a woman is valued, above all, for the financial benefits one can extract from her family. ${ }^{73}$

See, e.g, United States v. Tunnell, 667 F.2d 1182 (5th Cir. 1982).

Id. at 1186.

Nussbaum, 'Whether from Reason or Prejudice': Taking Money for Bodily Services, 27 Legal Studies (1998), pp. 693, 700. 
Indeed, Igor Primoratz has gone so far as to assert that 'there is no morally significant difference between the common prostitute and the spouse in what used to be called a marriage of convenience. ${ }^{74}$ This kind of marriage, Primoratz quotes Engels as saying, 'turns often enough into the crassest prostitution-sometimes of both partners, but far more commonly of the woman, who only differs from the ordinary courtesan in that she does not let out her body on piecework as a wage worker, but sells it once and for all into slavery. ${ }^{75}$

Whatever one thinks of Engels' characterization of marriage as 'slavery', the fact remains that, even in our contemporary world, the line between sex 'for love' (or pleasure, procreation, or spousal duty) and sex 'for money' is not always a bright one. As Roy Baumeister and Kathleen Vohs have argued, female sexuality can be understood as a valuable resource. Because male sexuality is said to be less valuable in comparison, heterosexual intercourse is not an equal exchange. 'To make the exchange equal', they say, 'the man must give [the woman] something else in return. ${ }^{.76}$ And the thing given sometimes takes the form of valuable property. ${ }^{77}$ Indeed, a large empirical study of American couples by Philip Blumstein and Pepper Schwartz found that 'financial considerations influenced sexual behavior. In particular, women who lacked their own independent means of financial support ... felt less able or less willing to refuse their husbands' sexual advances, as compared to other women'. ${ }^{78}$

74 Primoratz, What's Wrong with Prostitution?, 68 Philosophy (1993), pp. 159, 160.

75 Id. (quoting Engels, The Origin of the Family, Private Property and the State (trans. A. West) (Penguin, 1985), p. 102).

76 Baumeister and Vohs, Sexual Economics: Sex as a Female Resource for Social Exchange in Heterosexual Transactions, 8 Personality and Social Psychology Review (2004), p. 339.

77 In Mozambique, according to one source, husbands are expected to give their wives gifts of money in return for sex. Arnfred, Sexuality \& Gender Politics in Mozambique: Rethinking Gender in Africa (James Currey Publishers, 2011), p. 194.

78 Baumeister and Vohs 2004, p. 348 (citing Blumstein, American Couples: Money, Work, Sex (William Morrow, 1983)). Though it should be noted that the sex-as-economic-transaction theory probably has less salience in the context of marriage than elsewhere because, as Baumeister and Vohs put it, 'commitment has already been made, because material property is jointly owned and therefore not available for exchange, and because the marital contract regarding sex removes the couple from the competitive marketplace'. Id at 359. 
Presumably anticipating such cases, several American jurisdictions have expressly defined prostitution to exclude 'marital intercourse ${ }^{79}$ or sexual acts with one's 'spouse.8 ${ }^{80}$ But the question remains whether it makes sense to do so.

Until approximately thirty years ago, rape within marriage was widely exempt from prosecution as well. Defenders of such laws argued, among other things, that they were necessary to prevent governmental intrusion into matters of marital privacy. ${ }^{81}$ Such arguments have mostly been rejected, and the marital rape exemption has largely been repealed. Should that development have any bearing on what we might call the 'marital prostitution exemption'? As we'll see below, it depends on what the purpose of prostitution law is in the first place. Assuming, for the moment, that it is mainly meant to protect women from being coerced or exploited into having sex they do not wish to have, and given that such coercion and exploitation can undoubtedly occur within the marital relationship, there is at least a prima facie argument for doing away with such an exemption, at least on the 'buyer's' side.

Even if the marital prostitution exemption were to be maintained, however, we would still need to contend with cases involving non-marital monogamous or semi-monogamous relationships. Consider, first, cases in which so-called 'sugar babies' agree with their 'sugar daddies' to exchange companionship and sexual favours for college tuition, living expenses, clothing, jewelry, or other valuable property. ${ }^{82}$ Should such exchanges be regarded as prostitution?

I would argue that what distinguishes relationships like these from those in more conventional cases of prostitution is that they are essentially 'exclusive' in character. Prostitution has often been described, in both statutory and case law, as involving not just sex for money, but sex for money that is 'indiscriminate', 'promiscuous', or (in the

$79 \quad$ E.g. Wisconsin Rev. Stat. $\$ 944.30(1 \mathrm{~m})(\mathrm{a})$.

80 E.g. Colorado Rev. Stat. $\$ 18-7-201(1)$. Hawaii Rev. Stat. $\$ 712-1200$ (defining 'sexual contact' as 'any touching ... of the sexual or other intimate parts of a person not married to the actor').

$81 \quad$ See, e.g, People v. Liberta, 474 N.E.2d 567, 574 (N.Y. Ct. App. 1984) (considering and rejecting this argument).

82 See generally Motyl, Note, Trading Sex for College Tuition: How Sugar Daddy 'Dating' Sites May be Sugar Coating Prostitution, 117 Penn State L. Rev. (2013), pp. 927, 929; see also Miller 2010. To cite one particularly notable case, Donald Sterling, the 80 -something former owner of the Los Angeles Clippers basketball team, reportedly gave his 30-something mistress, V. Stiviano, more than \$3.6 million in gifts, including a duplex apartment, a Ferrari, two Bentleys, a Range Rover, jewelry, luggage, and designer clothes. See Lindsey Bever, Donald Sterling's Estranged Wife Wins Back Millions He Lavished on V. Stiviano, Washington Post (April 15, 2015), http:// www.washingtonpost.com/news/morning-mix/wp/2015/04/15/donald-sterlings-estrangedwife-wins-back-millions-he-lavished-on-mistress/ 
words of Swedish law) 'casual'. ${ }^{83}$ Unlike the conventional prostitute, who may have sex with numerous partners in a day, the paid 'mistress' typically has just one 'client' over an extended period of time, from whom she may derive not just money but also affection, prestige, and mentoring. ${ }^{84}$

A similar dynamic may exist in the case of so-called 'office romances' in which a junior corporate executive agrees to have sex with a powerful senior executive, on an ongoing basis, in return for a promotion or raise (an apparently not uncommon practice ${ }^{85}$ ). While some cases of this type could be handled (civilly) as sexual harassment, or (criminally) as an abuse of position, many could not. For example, imagine that the junior party has entered into the relationship without being pressured to do so, perhaps even on her own initiative. Does it make any sense to think of such cases as prostitution?

The 'office romance' cases differ from the paradigmatic case of prostitution, it seems to me, in two key ways: First, as in the marriage and sugar daddy cases, the relationships involved are more or less 'exclusive.' Second, as in the Tunnel case (involving the Texas justice of the peace), sex is exchanged for a non-propertised benefit. We would have to have a quite broad rationale for criminalising prostitution to justify including such cases within the meaning of the offence.

\section{(e) Therapeutic Sex}

Finally, we consider a class of cases that, though they do involve both 'sex for money' and non-'exclusive' relationships, nevertheless test the limits of what constitutes prostitution.

83 See Sweden Penal Code Section 6.11; Louisiana Rev. Stat. Title 14, $₫ 82$ (prostitution is 'indiscriminate sexual intercourse with others for compensation'); Vermont Stat. Ann. Title 13, $\$ 2631$ (prostitution includes offering or receiving the body for indiscriminate sexual intercourse without hire); Oklahoma Stat. Ann. Title 21, $\$ 1030$ (prostitution is lewdness in exchange for money; lewdness is defined as 'the giving or receiving of the body for indiscriminate sexual' activity with person not one's spouse). See also People v. Head, 304 P.2d 761 (Cal. App Ct. 1956) ('Prostitution is the common, indiscriminate, illicit intercourse of a woman for hire.); Colletti v. Morehead, 50 N.Y.S 2d 78, 81 (1944); Trent v. Commonwealth, 25 S.E.2d 350 (Va. 1943) ('prostitution' means common, indiscriminate, illicit intercourse for hire).

84 There is also a considerable gray area in between. So, for example, $X$ may build a small, exclusive client list of people with whom she has sex in return for expensive gifts, while $Y$ may be willing to have sex with any man who buys her dinner. (Thanks to Jeremy Horder for pressing me on this point.)

85 According to a recent study from the Center for Work-Life Policy, more than half of American corporate executives surveyed (both men and women) believe that 'when a junior woman is having a sexual dalliance with the boss . . . salary hikes and plum assignments are being traded for sexual favors. Hewlett, How Sex Hurts the Workplace, Especially Women, Harvard Business Review blog (Aug. 24, 2010), https://hbr.org/2010/08/how-sex-hurts-the-workplace-es. 
I have in mind the kind of 'therapeutic sex' depicted in the 2012 film The Sessions, based on a true story, in which a man suffering from polio and forced to live in an iron lung has a series of encounters with a professional sex surrogate. ${ }^{86}$ Given its sexual, 'promiscuous,' and commercial character, is there anything to exempt such conduct from being prosecuted as prostitution?

So far as I can tell, there are no reported criminal cases in which the question has been considered. But the issue has arisen as a matter of professional ethics. In France, neither buying nor selling sex was a crime until this year (when the law was changed to criminalise the former). Yet, in 2013, the French National Ethics Committee opined that sexual surrogacy constitutes an 'unethical use of the human body for commercial purposes. $^{87}$

Although not without controversy, such therapy (originally described by Masters and Johnson in their 1970 textbook, Human Sexual Inadequacy) is viewed by some in the medical profession as an effective and appropriate therapy for people with extreme anxiety about sex and, increasingly, to fulfill the needs or desires of people with serious disabilities. ${ }^{88}$ Sherry Colb has suggested that we think of the relationship between ordinary prostitution and sexual surrogacy as analogous to that between recreational and medical marijuana use. ${ }^{89}$ Under this approach, even if sexual surrogacy did constitute a prima facie case of prostitution, it might make sense to allow its practitioners a justification-type defense to any criminal charges. On the other hand, as Colb recognises, while people use medical marijuana to ease 'what would otherwise be nearly intolerably painful health problems', it is not clear that the problems faced by those who use sexual surrogates really compare.

As we shall see in a moment, one of the most compelling arguments for continuing to criminalise at least some buying of sex is to prevent the exploitation and coercionof sellers-that often occurs. In the case of sexual surrogacy, the potential for exploitation of the seller seems minimal. If anyone is likely to be the victim of exploitation, it is probably the buyer. ${ }^{90}$ The professional norms that ordinarily govern relations between

86

87 Hamblin, Intimacy in an Iron Lung, The Atlantic (July 9, 2013), http://www.theatlantic.com/ health/archive/2013/07/intimacy-in-an-iron-lung/277606/; see also de la Baume, Disabled People Say They, Too, Want a Sex Life, and Seek Help in Attaining It, New York Times (July 4, 2013), http://www.nytimes.com/2013/07/05/world/europe/disabled-people-say-they-too-wanta-sex-life-and-seek-help-in-attaining-it.html

88 Rosenbaum et al., Surrogate Partner Therapy: Ethical Considerations in Sexual Medicine, 11 Journal of Sex Medicine (2014), p. 321.

89 Colb, Sexual Surrogacy: Better Than Prostitution?, Justia.com (July 24, 2013), https://verdict.justia. com/2013/07/24/sexual-surrogacy-better-than-prostitution. Though it is worth considering the possibility that even 'recreational' marijuana and prostitution could have therapeutic benefits.

90 Colb makes a similar point. 
therapists and patients, and which strictly prohibit sexual relations, are severely tested by such surrogacy. ${ }^{91}$ There may well be good reasons for prohibiting sexual surrogacy, whether criminally or as a matter of professional ethics, but it is doubtful that prostitution law offers a particularly appropriate method for doing so.

\section{Rationales for Prohibiting Prostitution}

So far, we have considered how various jurisdictions have determined what counts as prostitution as a matter of positive law. In this section, we finally turn to the normative question-namely, what should count as prostitution? As we shall see, there is no onesize-fits-all answer. The only way to determine what should count as prostitution is by considering why buying or selling sex are considered wrong, or appropriate for reduction or deterrence, in the first place; and those, of course, are highly contested questions. To illustrate, I intend to consider five commonly-offered rationales for criminalising, or at least regulating, the sale or purchase of sex. These are: (1) protecting religious values and family integrity; (2) protecting the health of sex workers and the public; (3) preventing violence against sex workers; (4) preventing objectification of women and commodification of sex; and (5) preventing economic exploitation and oppression of sex workers and of women generally. I hope to show how the choice of rationale will ultimately determine how we answer the 'what counts as prostitution' question.

\section{(a) Methodology}

Before we can begin, I need to explain a number of ways in which the discussion will be limited:

First, my goal is to articulate the basic gist of a representative range of some of the most influential arguments for prohibiting or regulating prostitution or for believing that it is wrong. I present the arguments in broad strokes, offering little of the detail and nuance that can be found in the voluminous scholarly literature. In some cases, I have sought to simplify matters by grouping what I perceive as related arguments under a common heading (e.g., objectification and commodification). In other cases, I have sought to distinguish between arguments that other scholars may conflate. Even if readers disagree with how I have articulated, or grouped, one or more of these rationales, I hope they will nevertheless be persuaded that, in deciding the definitional issue, the rationales we choose are decisive. 
Second, I make no sharp distinction between arguments for why prostitution is wrong and arguments for why it should be criminalised, reduced, or regulated. Although the issues are conceptually distinct (one could certainly believe that buying or selling sex were wrong without believing that they should be criminalised or regulated, and vice versa), what matters for present purposes is that both kinds of arguments are relevant to the 'what should count as prostitution' question. For similar reasons, I shall not attempt to distinguish between arguments for why prostitution is inherently wrong and arguments for why it is contingently so. Nor shall I distinguish between arguments for why it should be criminalised and arguments for why it should merely be regulated.

Third, I make no clear distinction between the act of buying sex and that of selling it. Even if only one side of the transaction (most likely, the purchase) were to be criminalised or prohibited, we would still need to know what counts as prostitution. Similarly, I make no sharp distinction between the core acts of buying and selling sex, on the one hand, and related acts such as pimping, brothel-keeping, street walking, and kerb crawling, on the other. The concepts of buying and selling sex are logically prior to those of pimping, brothel-keeping, and the like. Thus, even if a given jurisdiction were to criminalise only the latter sort of act, it would still need to formulate a conception as to what constituted the former.

Fourth, the rationales I consider are not meant to be mutually exclusive. As the rhetoric surrounding current Nordic prostitution regimes suggests, most of the rationales are complementary and cumulative. ${ }^{92}$ Thus, even if a given rationale was not sufficient by itself to justify criminalisation, combined with one or more other rationales, it might well be.

Fifth, and crucially, I take these rationales more or less as I find them, making no attempt to assess the normative or empirical claims on which they rest. For example, I do not consider how frequently sex workers are in fact subject to coercion, exploitation, harassment, infection, mental health problems, or violence. I do not consider how the experience of sex workers is likely to differ depending on the circumstances in which they practice-for example, whether they are engaged in 'indoor' vs. 'outdoor' prostitution, are high-paid 'call girls' or low wage 'street walkers', brothel employees, or 'window workers. Nor do I consider the differences between female and male sellers (or buyers) of sex. Instead, I simply ask what the implications would be with respect to the definitional question, taking these various rationales, and the empirical claims on which they are based, at face value.

92 See Skilbrei and Holmström, Is There a Nordic Prostitution Regime?, 40 Crime and Justice (2011), p. 479; Fleharty, Comment, Targeting the 'Tricks' of the Trade: A Comparative Analysis of Prostitution Laws in Sweden and the United States, 15 Oregon J. International Law (2013), pp. 443 , at $448-450$. 
Sixth, just as I do not assess the evidence regarding the conditions under which prostitutes actually work, I also refrain from assessing the extent to which a given approach to criminalisation would be likely to achieve its stated goals. Thus, I do not consider the possibility that some forms of criminalisation, rather than reducing the risks of stigmatization, violence, or disease to which sellers of sex are subject, might actually increase them. I do not consider the possibility that criminalisation might infringe on any individual's rights to sexual autonomy, or that allowing people to sell sexual services, might, under the right circumstances, be 'empowering. Nor I do consider the 'fit' between criminalisation and the problems it is supposed to address. For example, I do not consider the possibility that some of the arguments for why prostitution should be criminalised are under- or overinclusive.

Finally, in articulating the various arguments that have been offered to explain why prostitution is wrong or should be deterred or discouraged, I will not attempt to say whether a given rationale meets the requirements of liberal criminalisation theory more generally. For example, I will not consider the possibility that, even if sellers of sex cause serious harms to themselves, such harms might fail to provide an appropriate basis for criminalisation in a liberal society. More generally, I shall resist categorizing various justifications for criminalising prostitution as involving 'harms to others', 'harms to self', 'offense to others', or 'legal moralism', or excluding them from consideration simply because they are inconsistent with a liberal approach to criminalisation.

\section{(b) Five Rationales for Why Prostitution is Wrong or should be Criminalised}

\section{- Protecting Religious Values}

From a traditional, Western, Judeo-Christian perspective, there are essentially two related and overlapping justifications for prohibiting prostitution. One is premised on the view that the only kind of sex that is morally permissible is that which occurs within a heterosexual, monogamous, marital relationship, and which has procreation as its main purpose. Sex that does not meet this paradigm is regarded as immoral. Under this view, prostitution would be regarded as immoral for the same reasons fornication and adultery would be regarded as immoral. ${ }^{93}$ The second justification views the ban on prostitution as

93 See, e.g., Wurmbrand, Prostitution, in Encyclopedia Judaica (Macmillan, 2d ed. 2006), vol. 16, pp. 625, 626 ('every sexual act between a man and a woman outside marital relations was considered as coming within the definition of prostitution (be'ilat zenut), and the rabbis strongly condemned manifestations of sexual license in the Jewish community'). For a similar, Christianbased, rationale, see Devlin, The Enforcement of Morals (Oxford U. Press, 1965), pp. 12, 179 (written in response to the 1957 Wolfenden Committee Report on Homosexual Offences and Prostitution). 
a means to preserve the integrity of the family, prevent divorce, and assure that children are conceived within a (heterosexual) marital home. ${ }^{94}$

Taking the religious position at face value, what would we expect its implications to be with respect to the 'what counts as prostitution' question? As far as I am aware, there is no discussion of the issue within the religious literature itself. We can, however, make some educated guesses.

To the extent that society is interested in channeling sexual desire into procreative activities, preventing the 'wasting' of sperm, and preserving family harmony, we would expect a fairly broad definition of prostitution. Under this approach, oral and anal sex, happy ending massage, and even lap dancing would all arguably fall within the scope of what counts as prostitution. On the other hand, if the main reason for prohibiting prostitution was to prevent out-of-wedlock births, we would expect a rather narrow definition of the offense, limited essentially to vaginal intercourse.

Under either religious rationale, the 'commercial' aspect of prostitution would be of relatively little importance. What makes prostitution wrong, according to the religious approach, is not so much that sex is being paid for, but that it is almost invariably extramarital and promiscuous. ${ }^{95}$ We would therefore expect the moralist to embrace the marital prostitution exemption. So long as the sex was obtained within the confines of marriage (and involved vaginal intercourse), there would be no reason to prohibit it simply because it was bought. On the other hand, 'sugar daddy', 'office romance', and professional surrogate sex would all presumably remain illicit, since all involve sex that occurs outside the realm of marriage.

\section{- Protecting the Health of Sex Workers and the Public}

Historically, one of the most important rationales for criminalising prostitution has been protecting the public health and preventing the spread of disease. Indeed, it was such

94 As the U.S. Supreme Court characterized commercial sex workers in 1908, '[t]he lives and examples of such persons are in hostility to "the idea of the family, as consisting in and springing from the union for life of one man and one woman in the holy estate of matrimony; the sure foundation of all that is stable and noble in our civilization, the best guaranty of that reverent morality which is the source of all benevolent progress in social and political improvement"'. United States v. Bitty, 208 U.S. 393, 401 (1908) (quoting Murphy v. Ramsey, 114 U.S. 15, 45 (1885)).

95 As Aquinas put it, 'paying a prostitute for fornication involves money given for something unlawful, but the giving itself is not unlawful'. Thus, the prostitute 'may keep her fee' and is not obliged to give it back to the customer' (unless, that is, she demands too much for her services). See Dever, Aquinas on the Practice of Prostitution, in Essays in Medieval Studies: Proceedings of the Illinois Medieval Association (vol. 13, 1996), available at http://www.illinoismedieval.org/ ems/VOL13/dever.html (quoting Thomas Aquinas, Summa Theologiae, vol. 2-2.32.7). 
concerns that gave rise to the first wave of modern prostitution statutes, the English Contagious Diseases Acts of the 1860s, which allowed police officers to arrest prostitutes in certain ports and garrison towns, and subject them to compulsory checks for venereal disease. ${ }^{96}$ Protection of public health was also a leading rationale of American prostitution laws in the Progressive Era of the early 20th century. ${ }^{97}$ The argument here is not that buying or selling sex should be prohibited because they are intrinsically wrong, but rather, because of the way they are practiced in the real world.

Although 19th and early 20th century reformers seem to have been concerned primarily with the health of sex buyers, today it is recognized that the most significant health risks are to sex sellers, especially those who work the streets. ${ }^{98}$ In addition to HIV and other venereal infections, sex workers often suffer from gynecological, palatal, and mental health problems, including post-traumatic stress, depression, anxiety, and dissociative orders. ${ }^{99}$ As a result, even those jurisdictions that have decriminalised both the buying and selling of sex, such as the Netherlands and Nevada, continue to regulate it.

For purposes of this discussion, let us take at face value the idea that preventing the spread of disease offers a rationale for prohibiting or regulating the buying and selling of sex. ${ }^{100}$ What would be the implications of such a view with respect to the 'what counts as prostitution' question?

My best guess is that we would end up with a relatively narrow definition of both the 'sexual conduct' and 'exchange' elements. Even if the public health rationale did justify prohibiting or regulating (the purchase, if not the sale of) penetrative sex for hire, it would provide relatively little justification for prohibiting or regulating non-penetrative sex, involving, say, lap dancing, sadomasochistic conduct, breast touching, or genital stimulation. On the other hand, there would be no basis not to include penetrative sex in which the seller's fee was paid by a third party. Slightly less clear would be cases in which the buyer pays to watch two or more other people having sex (as in Taylor, Wooten, and Freeman). Assuming that the sex was penetrative, serious health concerns would still

96 I review this history in Green, Vice Crimes and Preventive Justice, 8 Criminal Law and Philosophy (2013), p. 561.

97 See id.

98 For a useful summary of the evidence, see Law, Commercial Sex: Beyond Decriminalization, 73 Southern California L. Rev (2000), pp. 523, at 545-552.

99 See Dempsey, Sex Trafficking and Criminalization: In Defense of Feminist Abolitionism, 158 U. Pennsylvania L. Rev. (2010), pp. 1729, at 138-139.

100 Though it should be noted that there is reason to believe that, among some populations, casual, non-commercial sex is at least as common a transmitter of disease as prostitution. See Kelland, Disease Risk Higher for Swingers than Prostitutes, Reuters.com (June 23, 2010), http://www. reuters.com/article/us-sex-diseases-swingers-idUSTRE65M6NX20100623 (reporting on Dutch study). Assuming that's true, it would suggest that legislation prohibiting commercial sex is woefully underinclusive. 
be present for the performers themselves (though the risk to the broader 'public' would presumably be less).

And how would the disease-prevention rationale play out with respect to defining the proper limits of 'exchange'? It certainly should not matter that sex was exchanged for something other than money, such as the monthly rent or a ride across town. The cases where the disease-prevention rationale would lead to a significantly different outcome are those involving essentially 'exclusive' relationships, whether marital, sugar-baby, or office romance. In the case of marital prostitution, the risk of disease would be no greater than in the case of ordinary marital sex. And in the case of office romance and sugar baby relationships, the risk of spreading disease would be no greater than in other cases of (non-commercial) adultery or fornication.

\section{- Preventing Violence against Sex Workers}

In addition to the risk of infection, commercial sex workers also face the danger of violence and physical abuse. Women who sell sex are far more likely than the general population to be raped, beaten, and even killed. ${ }^{101}$ According to one controversial Canadian study, the mortality rate among prostitutes was found to be forty times the national average. ${ }^{102}$

There is a debate about whether criminalising prostitution alleviates such risks, or actually exacerbates them, since women who are engaged in illegal (as opposed to legal) prostitution are probably more likely to be abused in the first place, and less likely to report such violence to the police or to be taken seriously when they do ${ }^{103}$ For present purposes, we need not resolve the issue. Rather, I want to ask the same question I have been asking all along: if we take this rationale at face value, what would the implications be with respect to what should count as prostitution?

The answer is likely to turn almost entirely on empirical findings. There are data indicating that the incidence of violence against prostitutes who work 'outside' is considerably greater than that committed against those who work 'inside.' ${ }^{104}$ This would suggest, at a minimum, that sugar baby, office romance, and marital cases should be excluded from the definition of prostitution. I am not aware of any data, however, correlating the incidence of violence with the sale of specific types of sexual activity. If it turned out that,

$101 \quad$ Law 2000, p. 533.

102 Id.

103 See, e.g., Cunningham and Shah, Decriminalizing Prostitution: Surprising Implications for Sexual Violence and Public Health, National Bureau of Economic Research Working Paper No. 20821 (2014), http://www.nber.org/papers/w20281

104 See Weitzer, Sex Work, Gender, and Criminal Justice, in The Oxford Handbook of Gender, Sex, and Crime, eds. Gartner and McCarthy (Oxford U. Press, 2014), pp. 508, at 514. 
other things being equal, the risk of violence from commercial non-penetrative sex was less than that from commercial penetrative sex, we should be less likely to want to define the former as prostitution.

\section{- Preventing the Commodification of Sex and the Objectification of Women}

Two additional, closely related grounds for condemning prostitution are that it involves (1) the 'commodification' of sex, and (2) the 'objectification' of women. Both arguments seem to go to the inherent structure of prostitution, rather than to the social environment in which it is actually practiced.

The argument regarding objectification is that buying sex 'objectifies the seller, insofar as it entails interacting with and caring about parts of the seller that are bodily and incidental; sometimes it involves a desire that the prostitute be either passive or easily controlled, suggesting a further sense in which a person is treated as not fully human, or as an object'. ${ }^{105}$ According to the advocates of this approach, treating women this way fails to recognize them as free and equal persons, dehumanizes them, and encourages their victimisation.

The argument from commodification follows a similar tack. It says that, because persons' bodies and sexual capacities play an integral role in defining their identity, one who works as prostitute sells her personhood and therefore herself. ${ }^{106}$ According to this view, prostitution is a transaction in which one person must be defined as a social subordinate who caters to the desires of another. ${ }^{107}$

The commodification argument, as I understand it, is dependent on a particular view of what constitutes 'good' or 'moral' sexual conduct. As Elizabeth Anderson has explained, the good of sex is:

105 Marino, Prostitution, in, The International Encyclopedia of Ethics, ed. LaFollette (Wiley-Blackwell, (2013). For a critique and elaboration of the objectification view, see Nussbaum, Sex and Social Justice (Oxford University Press, 1999), pp. 214-218. Kant's critique of prostitution can also be understood as resting on a theory of objectification. See Kant, Lectures on Ethics (Louis Infield, trans.) (Hackett, 1930), p. 165 ('Human beings are ... not entitled to offer themselves, for profit, as things for use of others in the satisfaction of their sexual propensities. In so doing they would run the risk of having their person used by all and sundry as an instrument for the satisfaction of inclination'.).

106 Shrage, Feminist Perspectives on Sex Markets, Stanford Encyclopedia of Philosophy (first published, 2004), http://plato.stanford.edu/entries/feminist-sex-markets/\#Pro. For further discussion and critique, see Nussbaum, 'Whether from Reason or Prejudice': Taking Money for Bodily Services, 27 The Journal of Legal Studies 693, 695 (1998); Satz, Markets in Women's Sexual Labor, 106 Ethics 63, 70 (1995); and Radin, Contested Commodities: The Trouble with the Trade in Sex, Children, Body Parts, and Other Things (Harvard U. Press, 2001).

$107 \quad$ See Shrage 2004. 
realized only when each partner reciprocates the other's gift in kind, offering her own sexuality in the same spirit in which she received the other's -- as a genuine offering of the self. The commodification of sexual "services" destroys the kind of reciprocity required to realize human sexuality as a shared good, [and may corrupt non-market sexual relationships by promoting the valuation of women in terms of their market worth]. ${ }^{108}$

Under this view, buying and selling sex are seen as wrongful because they undermine the value of sex and, ultimately, the value of the individual who engages in them.

Although conceptually distinct, the two critiques are closely related. It is hard to imagine any form of commodification that did not also involve objectification. And while one could certainly objectify without commodifying, commodification seems to involve a particularly strong form of objectification.

So what are the implications of these two critiques with respect to the 'what constitutes prostitution' question? It would seem that a very wide range of sexual acts, whether or not paid for, could entail objectification. This would be true not only in the case of sexual penetration, but also with respect to non-penetrative and even non-contact sexual encounters, such as those that occurred in Keawe (lap dancing), Georgia (sadomasochism), Begley (stripper) and Turnpaugh (sex worker masturbating). And when such acts are being performed for money, the potential for social subordination, the undermining of reciprocity, and the corruption of non-market sexual relationships would seem to be all the greater.

As for the 'exchange' element, the same concerns would arise even if sex was given in return for something of value other than money, such as a ride across town (Edwards), a fur coat (Johnson), or a decision by the justice of the peace to look the other way while criminal acts were being performed (Tunnel). Somewhat more difficult are those cases in which, in return for sex, a husband gives his wife an allowance, a corporate executive promises to support a subordinate in her bid for promotion, or a wealthy patron pays the college tuition of his younger, dependent lover. On the one hand, such acts do involve penetrative sex for money. On the other hand, the opportunity for reciprocity and genuine offering of the self is arguably greater than in more conventional cases of 'by the hour' prostitution. If I am right, the argument for calling conduct of this sort prostitution would be weaker than in the typical case.

One can also imagine a plausible argument, made by the husband, the corporate executive, or the wealthy patron, that the money given to his wife, subordinate, or lover was being given not in return for sex, but rather as a mere incident to it. A similar claim has 
been made in cases involving surrogate mother agreements, where the so-called 'commodification of motherhood' is a concern. Many jurisdictions have decided that, while it is impermissible to pay a surrogate mother directly for her services, she may be compensated for her pregnancy-related expenses. ${ }^{109}$ Cases like Xiao (involving forty dollar drinks at a Honolulu nightclub) suggest that, despite its formalistic quality, an analogous argument could be successful in the context of prostitution.

\section{- Preventing Economic Exploitation and Oppression of Women (Liberal and Radical Versions)}

Perhaps the most influential contemporary rationale for criminalising the purchase of sex (though not its sale) turns on the idea that prostitution involves the oppression and exploitation of sex workers (and, in some formulations, of women generally). There are essentially two different versions of the oppression critique, one associated primarily with liberal feminism, and the other with radical feminism. The liberal approach looks to the contingent particulars of how sex workers are treated in the real world, while allowing for the possibility that some prostitutes might not be subject to exploitative conditions. The radical approach, by contrast, views the purchase of sex as inherently exploitative and oppressive. Under this view, buying sex is always wrong and appropriate for criminalisation. Both approaches overlap to some degree with the more specific arguments regarding public health, violence, objectification, and commodification, considered above.

The liberal approach is exemplified by the views of early 20th century American reformers such as Jane Addams, who sought legislation to protect prostitutes at a time when the economy was becoming increasingly industrialized, and young, single women were moving to the cities and entering the workforce. ${ }^{110}$ Addams was a significant influence on the 1911 report of the Vice Commission of Chicago, which spoke of the 'sad life of prostitution', the 'ghastly life story of fallen women', and the 'morally and physically debasing and degrading' effects of the practice. ${ }^{111}$ Today, the liberal approach is exemplified by scholars such as Peter de Marneffe, who has described sellers of sex as individuals caught up in an exploitative process 'commonly experienced as humiliating and abusive, and result[ing] in lasting feelings of worthlessness, shame, and self-hatred.' ${ }^{112}$

See, e.g., R.R. v. M.H., 689 N.E.2d 790, 796-797 (Mass. 1998).

See Langum, Crossing Over the Line: Legislating Morality and the Mann Act (University of Chicago Press, 1994), pp. 17-19. For a discussion of John Stuart Mill's views of prostitution, see Clare McGlynn, John Stuart Mill on Prostitution: Radical Sentiments, Liberal Proscriptions, in Nineteenth-Century Gender Studies, issue 8.2 (summer 2012), http://www.ncgsjournal.com/ issue $82 /$ mcglynn.htm

1111911 Chicago Report (quoted in de Marneffe, Liberalism and Prostitution, at p. 60).

112 de Marneffe 2010 p. 13. 
The radical approach is identified with late 20th century feminist scholars and advocates such as Catharine MacKinnon and Andrea Dworkin. They view the prostitution industry as a 'quintessential expression of patriarchal gender relations and male domination', a vehicle for inflicting coercion and exploitation on women. ${ }^{113}$ As Dworkin put it, 'prostitution in and of itself is an abuse of a woman's body. . . When men use women in prostitution, they are expressing a pure hatred for the female body.' ${ }^{114}$ Unlike liberal feminists, who tend to focus on how prostitution and other sex work affects the rights of women individually, radical feminists tend to focus on the rights of women collectively since, in their view, prostitution is the result of the subordination of the entire female gender.

According to the radical view, prostitution reflects deep structural inequalities between men and women, and perpetuates sexism, sex discrimination, and misogyny. Social and economic inequalities between men and women render it nearly impossible for a woman to actually 'choose' to become a prostitute. ${ }^{115}$ As Shulamit Almog explains, the very act of labeling an act of prostitution as 'consensual' is stigmatizing; the woman who consents in these circumstances is 'marked, abandoned, [and] disgraced ... separated by an abyss from all women who have not chosen to be prostitutes. ${ }^{116}$ On this view, prostitution and other forms of putatively consensual sex work are viewed as on par with unambiguously non-consensual offenses such as domestic violence, sexual assault, and rape.

And what are the implications of the liberal and radical views with respect to the 'what-counts-as-prostitution' question? Both the liberal and the radical theorist are likely to see the potential for exploitation not only in conventional prostitution, but also in other forms of sex work, such as appearing in pornography and working in strip clubs. ${ }^{117} \mathrm{On}$ this view, we would expect to see 'prostitution' defined quite broadly.

As for the 'exchange' aspects of prostitution, it seems likely that radical feminists (if not necessarily their liberal counterparts) would find cases involving marital, sugar daddy, and office romance relationships sufficiently exploitative and oppressive to be included in the same basket as more conventional forms of prostitution. All of these relationships

113 Weitzer, Legalizing Prostitution: From Illicit Vice to Lawful Business (NYU Press, 2012), at pp. 10-11; see also Dworkin, Prostitution and Male Dominance, in Life and Death (New York: Free Press, 1997), at p. 139; MacKinnon, Feminism Unmodified: Discourses on Life and Law (Harvard U. Press, 1987), at p. 158; MacKinnon, Toward a Feminist Theory of the State (Harvard U. Press, 1989); Dempsey 2010, pp. 1736-1739; Aronson, Note, Seeking a Consolidated Feminist Voice for Prostitution in the U.S., 3 Rutgers Journal of Law \& Urban Policy (2006), pp. 357, 370.

114 Dworkin 1997, p.145.

115 Pateman, The Sexual Contract (Stanford University Press, 1988), p. 207.

116 Almog, Prostitution as Exploitation: An Israeli Perspective, 11 Georgetown J. Gender and the Law (2011), p. 711.

117 Indeed, figures such as MacKinnon have been equally concerned with the exploitative effects of the pornography industry. MacKinnon 1987, p. 158. 
seem to reflect the same kinds of patriarchal and unequal relationships that lie at the core of more traditional forms of prostitution. There would thus be no reason to exempt such cases from liability.

\section{Defining 'Sex' and 'Sexual Conduct' in Other Criminal Law Contexts}

In the previous several sections, we observed the difficulty of trying to say what constitutes, or should constitute, 'sex' and 'sexual conduct' in the specific context of prostitution. In this concluding section, I suggest that analogous definitional quandaries arise in connection with a range of other sexual offenses as well, both consensual (such as adultery and adult incest), and nonconsensual (such as sexual assault).

\section{(a) 'Sex' in Ordinary Language}

Before we consider how 'sex' is defined in these legal contexts, it will be useful to consider briefly how the term is used in ordinary language. Those empirical studies that have been conducted have found that while almost all subjects agreed that penile-vaginal intercourse qualifies as sex, there is a significant variance with respect to a range of other forms of conduct. Consider, for example, the results of a 2010 study from the Kinsey Institute. The survey asked a representative sample of subjects, 'would you say you "had sex" with someone if the most intimate behavior you engaged in was . . . ?' Ninety five percent of all participants answered yes with respect to penile-vaginal intercourse, but a smaller percentage answered yes with respect to penile-anal intercourse (81 percent), having oral contact with a partner's genitals (71 percent), and touching or stimulating a partner's genitals (45 percent). ${ }^{118}$ A similar study was published in 1999, not long after Bill Clinton implied, in grand jury testimony, that he had not 'ha[d] sex' with Monica Lewinsky (who, it turns out, had fellated, but apparently not had intercourse with, him). ${ }^{119}$ In the study, approximately six hundred American college students were asked the same 'would you say you "had sex"' question. While there were some modest differences between the responses of men and women, a similar hierarchy emerged: More than 99 percent said they would be 'having sex' if they had engaged in penile-vaginal intercourse; 81 percent, penile-anal intercourse; 40 percent, oral contact with genitals; 15 percent,

118 See Sanders et al., Misclassification Bias: Diversity in Conceptualisations About Having 'Had Sex’, Kinsey Institute Research Paper (2010), http://kinsey.indiana.edu/publications/PDF/had\%20 sex\%20study.pdf

119 Reinisch and Sanders, Would You Say You 'Had Sex' If . . ?, 281 Journal of the American Medical Association (1999), p. 275. Although the study was published after the Lewinsky scandal broke, the data were obtained prior. 
having a person touch the genitals; and less than 5 percent, oral or digital contact with breasts or nipples, or deep kissing.

Both of these studies probably raise at least as many questions as they answer. ${ }^{120}$ First, it is important to recognize that the subjects were asked about the meaning of 'having sex', rather than being engaged in 'sexual conduct'. It is quite possible that some respondents understood 'having sex' as a euphemism for sexual intercourse, presumably a subset of the broader category of 'sexual conduct'. The studies also don't tell us much about context or demographics. In the case of the students, perhaps some were thinking about whether they could engage in such contact and still, for better or worse, consider themselves virgins. Perhaps they were concerned with issues of 'fidelity' to significant others. Perhaps their answers varied depending on their sexual orientation. In assessing their responses, it would be helpful to know what the subjects understood as the costs and benefits (to their mental health, self-esteem, reputation among their peers, and the like) of labelling some behaviour as 'having sex.' Would their answers have differed if they had been asked to make judgments about the conduct of others, rather than themselves? What if the person they were making a judgement about was their own regular sexual partner, who had been intimate with someone else? Would it matter if the conduct was performed in the context of a 'hook-up' or 'one-night stand', rather than in a long-term relationship? What assumptions did the subjects make based on the minimal description of the conduct given? Did the subjects assume that the contact was consensual? Would their answers have differed if they had been told that they had been forced or tricked or coerced into having such contact?

\section{(b) Adultery}

One of the reasons the "would you say you "had sex"' question generated such interest in the wake of the Lewinsky scandal was that it played an obviously crucial role in determining a moral and legal issue: only if Clinton had had sex with Lewinsky would he have committed adultery (at least with her). And Americans apparently still feel quite strongly about the wrongfulness of adultery (or at least the closely related act of 'having an affair'). According to a recent Gallup poll, only 8 percent of American adults surveyed considered 'married men and women having an affair' to be 'morally acceptable', a lower percentage than considered it acceptable to clone humans (15\%), engage in polygamy (16\%), or commit suicide (19\%), not to mention having a baby outside of marriage

120 The discussion in this paragraph is borrowed from Green, What are the Sexual Offences?, in The New Philosophy of Criminal Law, eds. Flanders and Hoskins (Rowman Littlefield, 2015), pp. 57, 62-63. 
(61\%), engaging in homosexual relations (63\%), or sex between an unmarried man and woman $(68 \%){ }^{121}$

The fact that people regard adultery as a moral wrong, however, does not necessarily mean they think it should be criminalised. Indeed, public opinion polls indicate that between two-thirds and three-quarters of those Americans surveyed believe that adultery should not be a crime for civilians. ${ }^{122}$ This may explain why, despite the fact it remains on the books in many U.S. jurisdictions, adultery is no longer prosecuted in civilian criminal courts $^{123}$ (though it continues to play a significant role in (civil) divorce proceedings and to provide a basis for court-martial proceedings in the U.S. military ${ }^{124}$ ).

Given its continued, if diminished, legal significance, it is worth asking how adultery has been, and should be, defined. A few statutes make it a crime simply to commit 'adultery', without further explanation, in a manner reminiscent of statutes that make it a crime to engage in 'prostitution. ${ }^{125}$ Those provisions that do define the act, including the U.S. Uniform Code of Military Justice, overwhelmingly require that a married person and someone who is not his spouse engage in the act of sexual 'intercourse' or

121 Newport, Americans Continue to Shift Left on Key Moral Issues, Gallup.com (2015), http:// www.gallup.com/poll/183455/once-taboo-behaviors-acceptable.aspx.

122 Rhode, Adultery: Infidelity and the Law (Harvard U. Press, 2016), at p. 22 (citing Associated Press and CNN/Gallup polls).

123 See Posner and Silbaugh 1996 pp. 103-110 (listing statutes). Whether a civilian criminal prosecution for adultery could even survive U.S. constitutional challenge seems doubtful. See Lawrence v. Texas, 539 U.S. 558, 599 (2003) (Scalia, J., dissenting) (predicting that adultery laws, along with laws against fornication, bigamy, adult incest, bestiality, and obscenity, could not survive majority's opinion striking down Texas' sodomy law). This is in contrast to other countries, especially in Asia, where adultery remains a crime. See, e.g., Xiaoying, Nearly 90 Percent Oppose Abolishing Crime of Adultery, China Daily (June 15, 2015), http://www. chinadaily.com.cn/china/2015-06/15/content_21008271.htm (poll data from Taiwan). But see Delman, When Adultery is a Crime, The Atlantic (March 2, 2015) http://www.theatlantic.com/ international/archive/2015/03/south-korea-adultery-law-repeal/386603/ (noting that South Korean Constitutional Court recently struck down country's adultery law).

124 Uniform Code of Military Justice, Art. 134, 62. Even in jurisdictions with no-fault divorce proceedings, evidence regarding adultery remains relevant with respect to property distributions, spousal support, and child custody. Pfeiffer, Virtual Adultery: No Physical Harm, no Foul?, 46 University of Richmond L. Rev. (2012), pp. 667, 675. See e.g., W.V. Code s. 61-8-3. 
'penetration.' ${ }^{26}$ Thus, in most states and in the military, 'lesser' forms of sexual contact would not constitute adultery. ${ }^{127}$

So exactly how should adultery be defined, whether in law or morality? The answer, of course, depends on why we think adultery is wrong or socially harmful in the first place (assuming we do). In 'traditional' societies, the reasons adultery was viewed as wrong were similar to the reasons prostitution was traditionally viewed as wrong-namely, that it involved sex that occurred outside of what was religiously permissible, was likely to undermine family integrity, violated a husband's property rights in his wife, and had the potential to raise questions about paternity. ${ }^{128}$ In practice, this meant that a wife's adultery was generally treated more harshly than a husband's. It also explains why adultery was defined so narrowly in law. As in the case of prostitution and common law rape, vaginal marital intercourse was the only kind of sex condoned by the law, so vaginal marital intercourse with someone other than one's spouse was the only kind of marriage transgression with which adultery law was properly concerned. A married partner who engaged in oral or anal sex in an extramarital relationship was engaging in conduct that was not permissible even within the marital bedroom; thus, the relationship could not be said to be harmed. ${ }^{129}$

In our age, of course, a far greater range of (consensual) sexual activity is viewed as morally 'acceptable,' or at least 'tolerable', both within marriage and among those who are not married. From this, one might infer that the definition of what constitutes adultery should also be broader. For example, in a recent divorce case from Louisiana, the

126 See sources cited in Posner and Silbaugh 1996 pp. 103-110. There is an interesting question about exactly which parties should be held liable for adultery. Imagine that $A$, who is married, has intercourse with $B$, who is not. The clear majority approach is to punish both $A$ and $B$, though there are several states in which only the married person would be criminally liable. (The New Hampshire adultery statute applies to both parties so long as the unmarried party knows that his partner is married - see N.H. Rev. Stat. $\$ 645: 3$.) One might think that the wrong entailed by adultery is committed in the first instance by the married party, not by the unmarried one. At most, $B$ would be aiding and abetting $A$ in a violation of $A$ 's marriage vows. For this reason, if adultery is to remain a crime (and I doubt very much that it should), the minority approach, under which only married offenders are punished, may be preferable.

127 Kentucky is unusual in having a statute that applies to 'intercourse or sodomy', see Kentucky Rev. Stat. section 392.090(2), while North Carolina law requires that the adulterous couple 'lewdly and lasciviously associate, bed, and cohabit together', see N.C. Gen. Stat. section 14-184.

128 See generally Rhode 2016 pp. 24-59. As the case of R. v. Mawgridge, (1707) Kel. 199, 84 ER 1107 at 1115 , famously put it (in the context of the provocation defense), '[w] here a man is taken in adultery with another man's wife, if the husband shall stab the adulterer or knock out his brains this is bare manslaughter: for jealousy is the rage of man and adultery is the highest invasion of property'. See also State v. Lash, 16 N.J.L. 380, 387 (N.J. Super Ct. 1838) ('The heinousness of [adultery] consists in exposing an innocent husband to maintain another man's children, and having them succeed to his inheritance.').

129 For a helpful elaboration of this point, see generally Coughlin, Sex and Guilt, 84 Virginia L. Rev. (1998), p. 1. 
defendant admitted that she and a man who was not her husband had shared a bed and touched each other's sexual organs, though she denied that they had had intercourse. In the absence of any statutory definition, the court determined that such non-coital contact was sufficient to constitute adultery. ${ }^{130}$ Some commentators, moreover, have even gone so far as to suggest that the concept of adultery should include cases of 'virtual,' online infidelities. ${ }^{131}$

Simply because our notion of what constitutes 'acceptable' sex is broader than it was at common law, however, does not necessarily mean that our notion of what constitutes adultery should also be broader. The reasons adultery is still so widely viewed as morally wrong today are clearly different than they were in traditional societies. To decide what should constitute adultery, we would need an adequate theory of why and how adultery is wrongful or harmful, and an understanding of what role the law and social stigma should play in its regulation. And the way we answer these questions may well vary depending on the precise context. For example, it appears that U.S. military law makes adultery an offense not because it is concerned with preserving the sanctity of marriage as such, but because adultery is said to be 'prejudicial to good order and discipline' and likely to bring 'discredit upon the armed forces.' ${ }^{132}$ By contrast, the reason ordinary civilians tell pollsters they regard adultery as wrongful may have more to do with moralized conceptions of loyalty, trust, and honesty within marriage.

\section{(c) Incest}

Analogous definitional questions arise in the context of incest law. Across U.S. jurisdictions, statutes differ with respect to what constitutes both the prohibited sexual act and the prohibited relation. A majority of statutes say that it is a crime to 'have intercourse with' or 'commit an act of sexual penetration' with a relative (defined variously as an ancestor, descendant, parent, child, grandparent, grandchild, aunt, uncle, nephew, niece, sibling, or first cousin, by blood or adoption or marriage). ${ }^{133}$ A minority make it a crime simply to 'perform a sex act' with a relative on the prohibited list. ${ }^{134}$

130 Bonura v. Bonura, 505 So.2d 143, 144 (La. Ct. App. 1987).

131 See Pfeiffer 2012; Cossman, The New Politics of Adultery, 15 Columbia Journal of Gender and Law (2006), pp. 274, 276-277; Hall, Sex Online: Is This Adultery?, 20 Hastings Comm. \& Entertainment L.J. (1997), p. 201; Varnado, Avatars, Scarlet 'A's, and Adultery in the Technological Age, 55 Ariz. L. Rev. (2013), p. 371.

132 Annuschat, Comment, An Affair to Remember: The State of the Crime of Adultery in the Military, 47 San Diego L. Rev. (2010), p. 1161.

133 Posner and Silbaugh 1996, pp. 129-142.

134 Ibid. Yet other statutes say that it is a crime to 'marry' a relative. 
So how should the 'sex' in incest be defined? Should it be limited to penetration, or should it apply to other 'lesser' sexual acts as well? Answering that question (as well as the question of what should constitute a prohibited familial 'relation') requires a consideration of why and how incest is wrong and should be criminalized (assuming it should be) in the first place.

These questions, of course, are contested, but three possible rationales can be mentioned: (1) preventing sexual abuse and sexual imposition, (2) protecting the family unit from intra-familial sexual jealousies and rivalries, and (3) reducing the risk that children will be born with genetic abnormalities. ${ }^{135}$ If incest laws were concerned exclusively with preventing genetic abnormalities, it would make sense to limit the offense to cases involving fertile partners of the opposite sex having vaginal intercourse without adequate contraception. To the extent that incest laws are concerned with preventing intra-familial sexual jealousies, a broader definition of sexual activity would seem warranted, since non-penetrative sexual contacts between family members may be as likely to be induce destabilizing jealousies as those involving penetration. And to the extent that the purpose of incest law is to prevent sexual imposition and abuse-that is, insofar as incest is essentially a non-consensual, rather than consensual, offence-an even broader definition would seem appropriate. The English Sexual Offences Act 2003 thus seems to take the right approach when it distinguishes, at the outset, between incest involving adults and incest involving juveniles. If the former, there must be 'penetration'; if the latter, any sexual 'touching' will suffice. ${ }^{136}$

\section{(d) Nonconsensual Offenses}

So far in this article, we have considered the definition of 'sexual conduct' as it appears in three distinct offences: prostitution, adultery, and incest. The first thing to note about adultery and adult incest (I leave to the side incest involving children) is that they are putatively consensual offenses. If there is any reason to criminalise them, it is not because anyone's sexual autonomy is being violated. Rather, it's because of some societal interest that is extraneous to consent and autonomy-presumably, the sanctity of marriage (in the case of adultery) or the integrity of the family (in the case of adult incest).

Because the underlying conduct is consensual, we would expect to see the offense defined fairly narrowly. Otherwise, there is a danger that the law might be applied in an overbroad manner, unduly infringing the right to sexual autonomy. For example, consen-

135 See generally Hörnle, Consensual Adult Incest: A Sex Offense?, 17 New Criminal Law Review 76 (2014); Bergelson, Vice is Nice But Incest is Best: The Problem of a Moral Taboo, 7 Criminal Law and Philosophy (2013), p. 43.

136 Sexual Offences Act 2003, ss. 64(1), 25(1), respectively. 
sually embracing or kissing a sibling or child or parent, or even observing them naked, might be treated as incestuous; and doing so with a friend or acquaintance who was not one's spouse could be treated as adulterous. By requiring that the consensual act being performed be penetrative, we minimize the possibility that the law will be applied too broadly.

When we turn to the nonconsensual offenses, however, we see a very different moral and legal landscape. Virtually every means of sexually imposing on $V$ without her consent (or, in some cases, without her assumption of risk) is wrong and potentially criminal -whether it is extremely intimate means such as having penetrative sex (as in rape), or less intimate means such as touching (as in sexual assault), watching her while she is nude (as in voyeurism), or subjecting her to unwanted sexual sights (as in indecent exposure). Here, we need not appeal to some interest that is extraneous to consent or autonomy, as we do in the case of adultery or adult incest. Here, it is precisely the lack of consent that makes the act wrong. The challenge of criminalising the nonconsensual offenses thus lies less in the danger of overcriminalising than it does in the need for grading. Although virtually all acts of nonconsensual sex will be wrong, they will not all deserve equal punishment; we will need a means of distinguishing the more serious acts from the less serious ones.

We do this, in the case of the nonconsensual offenses, by creating a range of separate offenses with separate punishments. Taking the English Sexual Offences Act 2003 as a model, we can see that Sections 2 and 3 involve nonconsensual penetration, Section 4 involves other kinds of nonconsensual touching, Section 66 involves nonconsensual exposure, Section 67 involves nonconsensual watching, and so forth. With the exception of sexual assault, ${ }^{137}$ which serves as a kind of safety-net provision, we need not be concerned with general 'what counts as sexual conduct' issues.

And what of prostitution? Would we expect its 'sexual activity' element to be defined narrowly, in a manner that is reminiscent of adultery and adult incest, or would we expect it to follow the broad approach to defining sex we have seen in the context of the nonconsensual offenses taken as a whole? That, in a sense, is the central puzzle we have been grappling with in this article. Those who view the selling of sex as an essentially consensual act will want to criminalise it-assuming they do-exclusively out of concern with matters that are extraneous to consent and autonomy, such as promoting public health and preventing violence. Their definition of what counts as 'sex' is likely to be a narrow one. By contrast, those who believe that prostitution is inherently coercive and exploitative, and therefore essentially nonconsensual, will tend to view almost every commercial

137 Under Section 3, sexual assault is defined to include non-consensual touchings of any part of the victim's body with any part of the offender's body or with anything else, provided that the 'the touching is sexual'. A touching would, in turn, be considered 'sexual' 'if a reasonable person would consider that it was of a sexual 'nature' or that its 'circumstances' or 'purpose' were sexual. 
sex transaction, both penetrative and non-penetrative, with suspicion. Their tendency will be to define the sex in prostitution more broadly.

Efforts to define the second element in prostitution - that of 'exchange'-will follow a similar path. Here we must decide whether to treat cases involving marital sex, 'office romances', 'sugar daddy' arrangements, and therapeutic treatment as prostitution. Also relevant here are cases involving the exchange of sex for non-propertised goods, such as official acts. Whether we ultimately decide to treat such cases as prostitution will depend, as before, on why we think prostitution is wrong or should be a crime in the first place. Those who are concerned primarily with preventing disease and violence will tend, once again, to prefer a narrow definition of exchange. Those who focus mainly on preventing objectification, commodification, exploitation, and oppression will likely favour a broader approach. 